\title{
Hubungan Promosi Kesehatan, Peran Masyarakat dan Peran Orang Tua terhadap Pencegahan Pedofilia
}

\author{
Uci Ciptiasrini $^{1}$, Robiatul Adawiyah ${ }^{2}$ \\ ${ }^{1,2}$ Program Studi Kebidanan Program Sarjana Terapan Sekolah Tinggi Ilmu Kesehatan Indonesia Maju \\ Jln.Harapan No 50, Lenteng Agung-Jakarta Selatan 12610. Indonesia \\ Telp: (021) 78894045, Email: '1uci.stikim@ gmail.com, ${ }^{2}$ robiatuladawiyah93@ gmail.com
}

\begin{abstract}
Abstrak
Pencegahan pedofila adalah untuk mencegah terjadinya kasus kekerasan seksual pada anak dengan mengajarkan anak tentang nama-nama bagian tubuh disertai dengan penjelasan fungsinya, termasuk mengajarkan anak tentang "bagian privat" seperti puting susu, genetalia, dan rectum. Tujuan penelitian ini adalah untuk mengetahui hubungan promosi kesehatan, peran masyarakat, dan peran orang tua terhadap perilaku pencegahan pedofilia pada anak 2-6 tahun di TK Al Muawwanah Tangerang Tahun 2018. Metode penelitian ini menggunakan rancangan penelitian deskriptik analitik dengan pendekatan cross sectional. Populasi dalam penelitian adalah orang tua TK Al Muawwanah Tangerang Tahun 2018. 60 responden sampel yang digunakan diambil dari total populasi yang ada, yang menjadi teknik pengambilan sampel. Penelitian ini menggunakan uji Chi-Square yang menunjukan hasil bahwa terdapat hubungan diantara promosi kesehatan dengan perilaku pencegahan pedofilia $(p$ value $=0,000$, OR 16,875), peran masyarakat dengan perilaku pencegahan pedofilia ( $p$ value $=0,000$, OR $12,600)$, dan peran orang tua dengan perilaku pencegahan pedofilia ( $p$ value $=0,000$, OR 11,550$)$. Saran dari penulis berdasarkan dari hasil penelitian ini adalah diharapkan agar orang tua dan guru memberikan pemahaman pada anak tentang kondisi tubuhnya dan perbedaan jenis kelamin. Pemahaman tersebut diberikan dengan cara memperagakan melalui media gambar, poster, lagu dan permainan.
\end{abstract}

Kata Kunci: Pedofilia, Kesehatan, Masyarakat, Orangtua

\begin{abstract}
Prevention of pedophilia is to prevent the sexual violence cases in children by teaching them about the names of body parts accompanied by explanation function, includes teaching them about "private section"As nipple, genetalia, and rectum. The purpose of this study is to know the relationship of health promotion, the roles of society and the role of parents in pedophilia prevention behavior to the 2-6 years old children in kinder garten Al Muawwanah Tangerang year 2018. This research method using design descriptive analytic research, with approach cross sectional. The population were parents kinder garten Al Muawwanah Tangerang year 2018. The 60 sample respondents used were taken from the total of the existing population, which became the sampling technique.The study used a Chi-Square test that showed the following results there is a relationship of health promotion with pedophilia prevention behavior ( $p$ value $=0,000$, OR 16,875), community role with pedophilia prevention behavior ( $p$ value $=0,000$, OR 12,600), and parent role with pedophilia prevention behavior ( $p$ value $=0.000$, OR 11,550). Suggestions from the authors based on the results of this study as followed, parents and teachers have to give understanding to the children about, the condition of their body and sex differences. The understanding is gives by demonstrating through the image, posters, song, and game.
\end{abstract}

Keywords: Pedophilia, Health, Society, Parent. 


\section{Pendahuluan}

Pelecahan seksual terhadap anak dibawah umur dan pelakunya adalah orang yang lebih dewasa dari korban, dan diduga juga dikenal oleh korbanya sendiri sehingga sulit untuk memantau apa yang terjadi dirumah, lembaga-lembaga dan sekolah. Salah satu bentuk tindak kejahatan terhadap anak adalah tindak pidana pedofilia. Pedofilia adalah seseorang yang memiliki perilaku seksual menyimpang dengan anak-anak. ECPAT International (End Child Prostitution In Asia Tourism), mengatakan para pedofil sering saling bertukar dan mengirim informasi tentang dimana dan bagaimana mengeksploitasi anak-anak. Dalam sebuah kasus pariwisata seks anak yang terorganisir dari meksiko, baik oleh para pedofil tersebut memang nampak. ${ }^{1}$

Kasus pengaduan anak berdasarkan klaster perlindungan anak Indonesia Tahun 2011-2016. Data anak sebagai pelaku kekerasan seksual (pemerkosaan, pencabulan, sodomi/pedofilia) Tahun 2011 terjadi sebanyak 2016 kasus, Tahun 2012 sebanyak 412 Kasus, tahun 2013 yaitu 343 kasus, dan pada tahun 2014 terjadi peningkatan yang cukup besar sebanyak 656 kasus, tahun 2015 ada sebanyak 218 kasus, dan pada tahun 2016 sebanyak 156 kasus. $^{2}$

Faktor penyebab terjadinya pelecehan seksual pada anak meliputi adanya orientasi ketertarikan seksual terhadap anak-anak (pedofilia), adanya pornomedia massa, dan ketidakpahaman anak akan persoalan seksualitas. $^{3}$

Dari data yang tercatat pada Komisi Nasional Perlindungan Anak Indonesia (Komnas PA) menyebutkan, laporan kasus pedofilia yang masuk ke lembaga terus meningkat. Tahun 2011, ada 2.011 kasus kekerasan terhadap anak, 59\% atau 1.480 di antaranya laporan pedofilia. Jumlah laporan kasus kekerasan seksual terhadap anak itu meningkat menjadi 1.628 kasus pada tahun 2012, dan 1.936 kasus pada tahun 2013. Adapun pada tahun 2014 hingga bulan april yang lalu sudah 179 kasus pedofilia yang dilaporkan ke Komnas PA Indonesia. ${ }^{4}$

Pedofilia adalah paraphilia, yang berarti keadaan dimana seseorang yang memiliki sebuah hubungan kuat dan berulang terhadap dorongan seksual dan fantasi tentang anakanak prapuber kemudian perasaan tersebut mengakibatkan penderitaan ataupun kesulitan interpersonal. $^{5}$

Pedofilia dibagi menjadi 2 jenis, yang pertama adalah pedofilia hormonal, yang merupakan kelainan biologis dan merupakan kelainan yang sudah di derita sejak lahir. Dan yang ke dua adalah, pedofilia habitual, yaitu kelainan seksual yang terbentuk dan terjadi akibat dari kondisi social penderita. ${ }^{7}$ Dalam pedofilia, yang dijadikan obyek seks adalah anal-anak yang berusia dibawah umur. Kegiatan ini biasanya berpusar dengan memain-mainkan alat kelamin anak, dan jika korbannya adalah anak perempuan dapat terjadi penetrasi vagina baik secara persial ataupun secara sempurna. Biasanya seorang pedofil dengan korbannya saling mengenal, termasuk mungkin juga tinggal saling berdekatan, dan hubungan tersebut telah berlangsung lama. Penyebab pedofil biasanya berupa faktor ketidak matangan, pengalaman belajar, atau psikopatologi. ${ }^{8}$

Pencegahan terjadinya pedofilia dapat dengan mengajarkan anak tentang nama-nama bagian tubuh disertai dengan penjelasan fungsinya, termasuk mengajarkan anak tentang "bagian privat" seperti puting susu, genetalia, dan rectum (anus). Hal tersebut harus di latih secara rutin mulai dari di rumah dan kamar praktik dokter anak pada usia 3 tahun. Pendidikan seks tersebut dilanjutkan di sekolah, anak harus di didik untuk mengatakan "tidak" jika disentuh oleh seseorang apa bila disentuh oleh orang lain di bagian tubuh privat, dan melaporkannya kepada orang dewasa yang dipercaya. Lingkungan sekitar anak seperti, pengasuh, teman-teman dan orang sekitarnya juga harus di teliti secara hati-hati oleh orang tuanya. ${ }^{9}$

Melihat dampak yang diakibatkan oleh kekerasan seksual yang dialami oleh anak-anak yang menjadi korban, maka dalam penanganan kekerasan seksual terhadap anak sangat penting peran aktif masyarakat, individu, dan pemerintah. Perlu adanya pendekatan berbasis sistem dalam penanganan kekerasan seksual anak. Sistem perlindungan anak yang efektif menyaratkan adanya komponen-komponen yang saling terkait. Komponen-komponen ini 
meliputi sistem kesejahteraan sosial bagi anakanak dan keluarga sistem peradilan yang sesuai dengan standar internasional dan mekanisme untuk mendorong perilaku yang tepat dalam masyarakat. Selain itu juga diperlukan kerangka hukum dan kebijakan yang mendukung serta sistem data dan informasi untuk perlindungan anak. Hasil penelitian berdasarkan pendekatan Precede Proceed terkait perencanaan dan pelaksanaan masingmasing kegiatan dalam upaya promosi kesehatan oleh kedua instansi dapat terlaksana dengan baik, sesuai dengan jadwal waktu dan tempat yang direncanakan. Namun masih secara umum tidak spesifik terkait penanganan kasus tindak pedofilia. ${ }^{10}$

Kasus kekerasan seksual yang melibatkan anak di wilayah Provinsi Banten masih terbilang tinggi. Hal itu diungkapkan ketua lembaga perlindungan anak (LPA) Provinsi Banten. Iip Syafruddin saat menggelar sosialisasi kekerasan terhadap anak di SMA Negeri 2 Kota Cilegon. Berdasarkan data LPA Provinsi Banten. Selama 2015 terdapat 317 kasus yang melibatkan anak. Sementara untuk 2016 hingga oktober tercatat sebanyak 110 kasus. Jika melihat dari data itu memang 2016 ini mengalami penurunan. Tapi jumlah itu terbilang cukup tinggi ungkap Iip syapruddin.

Dari studi pendahuluan yang dilakukan dengan wawancara pada 20 orang tua siswa TK Almu'awwanah yang mengetahui pedofilia 7 ibu dan mereka tahu secara definisi bahwa pedofilia seorang dewasa yang memilki perilaku seksual yang menyimpang pada anakanak dan mereka bersikap mengajarkan anak tentang pendidikan seksual sejak dini dengan mencontohkan dan mengajarkan anaknya untuk menutupi auratnya, terdapat 13 orang ibu yang tidak tahu tentang pedofilia dan ibu tersebut mengungkapkan kurang mengetahui kasus pedofilia dan dampak dari pedofilia dari 13 ibu tersebut merasa malu dalam memberikan pendidikan seksual pada anak dan bersikap menghindar bila anak bertanya seputar seks.

Berdasarkan latar belakang diatas peneliti tertarik untuk melakukan penelitian berjudul hubungan promosi kesehatan, peran masyarakat dan peran orang tua terhadap perilaku pencegahan pedofilia pada anak 2-6 tahun di TK Almu'awwanah Desa Talaga Kecamatan Cikupa Kabupaten Tangeran Provinsi Banten Tahun 2018.

Tujuan penelitian untuk mengetahui hubungan promosi kesehatan, peran masyarakat dan peran orang tua terhadap perilaku pencegahan pedofilia pada anak 2-6 tahun di TK Almu'awwanah Tangerang Tahun 2018.

\section{Metode}

Jenis penelitian ini menggunakan kuantitatif dengan metode penelitian deskriptif analitik dengan pendekatan cross sectional yaitu penelitian untuk menganalisis variabel dependen dan independen pada suatu periode yang sama pasa suatu waktu yang sama. ${ }^{11}$

Instrument atau alat ukur adalah hal yang sangat penting didalam kegiatan penelitian. Instrument memiliki peranan penting dalam menentukan suatu penelitian, karena validitas data yang diperoleh akan sangat ditentukan oleh kualitas instrument serta prosedur data yang ditempuh. ${ }^{12}$

Penelitian ini menggunakan data primer yaitu materi atau kumpulan data yang diperoleh peneliti pada saat penelitian berlangsung, yaitu termasuk data variabel dependen dan independen. Populasi penelitian adalah keseluruhan objek penelitian atau objek yang diteliti. ${ }^{11}$ Pada penelitian ini populasinya adalah seluruh orang tua siswa TK ALmu'awwanah sebanyak 60 orang. Untuk menentukan jumlah sampel, menurut Arikunto apabila subjek kurang dari seratus, sebaiknya diambil semua sebagai sampel. Tetapi jika jumlah subjek besar, dapat diambil $10-15 \%$ atau $15 \%-25 \%$ bahkan lebih. Pendapat tersebut sesuai dengan Roscoe yang mengatakan ukuran sampel yang layak adalah 30-500 subjek. Populasi dalam penelitian ini berjumlah kurang dari 100 responden, sehingga sampel yang diambil adalah total populasi.

Teknik sampling adalah teknik pengambilan sampel. Dalam pengambilan sampel dilakukan menggunakan sampling yang digunakan teknik Total Populasi artinya seluruh orang tua dari siswa TK Almu'awwanah dijadikan sampel penelitian. Hal ini dilakukan karena jumlah populasi 
memungkinkan bagi peneliti untuk meneliti secara keseluruhan. ${ }^{12}$

Kriteria inklusi adalah kriteria atau ciriciri yang perlu dipenuhi oleh setiap anggota populasi yang dapat diambil sebagai sampel. ${ }^{12}$ Kriteria inklusi adalah Semua orang tua dari siswa TK Almu'awwanah yang mempunyai anak usia 2-6 tahun dan bersedia menjadi responden.

Kriteria eksklusi adalah ciri-ciri anggota populasi yang tidak dapat diambil sebagai sampel. ${ }^{12}$ Kriteria ekslusi adalah Orang tua siswa yang berhalangan hadir saat penelitian seperti sakit. Kriteria yang tidak ada di Inklusi maupun Eksklusi. Orang tua yang memiliki anak usia 1-3 tahun, bukan orang tua siswa TK Almu'awwanah Desa Talaga Kecamatan Cikupa Kabupaten Tangerang.

Bertujuan untuk menjelaskan, mendeskripsikan karakteristik setiap variabel penelitian. Analisanya hanya menghasilkan distribusi frekuensi dan persentase dari setiap variabel. Analisa ini digunakan untuk menggambarkan distribusi frekuensi dari masing-masing variabel penelitian, yaitu variabel independen dan variabel dependen.

Penelitian ini menggunakan uji cji square karena data yang digunakan dalam bentuk data kategorik. Dalam penelitian kesehatan seringkali peneliti perlu melakukan analisis hubungan variabel kategorik dengan variabel kategorik. Analisis ini bertujuan untuk menguji perbedaan proporsi dua atau lebih kelompok sampel, dalam hal ini uji yang cocok digunakan yaitu chi square.

Analisa bivariat digunakan apabila ingin melihat hubungan antara variabel independen dan dependen. Melalui uji chi square akan diperoleh nilai $\mathrm{p}$ value, dimana dalam penelitian ini digunakan tingkat kemaknaan sebesar 0,05 . Penelitian antara dua variabel dikatakan bermakna jika mempunyai nilai $\mathrm{p} \leq$ 0,05 yang berarti $\mathrm{H}_{0}$ ditolak dan $\mathrm{H}_{\mathrm{a}}$ diterima. Dikatakan tidak bermakna jika mempunyai nilai $\mathrm{p} \geq 0,05$ yang berarti $\mathrm{H}_{0}$ diterima dan $\mathrm{H}_{\mathrm{a}}$ ditolak. Nilai OR merupakan nilai estimasi resiko untuk menjadi outcome sebagai pengaruh adanya variabel independen. Jika nilai $\mathrm{OR}>1$ berarti memiliki hubungan erat positif, sedangkan jika OR $<1$ berarti memiliki hubungan negatif dan jika OR $=1$ berarti tidak memiliki hubungan.

\section{Hasil}

Tabel 1. Gambaran Hubungan Promosi Kesehatan, Peran Masyarakat Dan Peran Orang Tua Terhadap Perilaku Pencegahan Pedofilia Pada Anak 2-6 Tahun Di TK Almu'awwanah Tangerang Tahun 2018

\begin{tabular}{lcc}
\hline Variabel & $\begin{array}{c}\text { Jumlah } \\
(\mathbf{n})\end{array}$ & $\begin{array}{c}\text { Persentase } \\
(\%)\end{array}$ \\
\hline Perilaku & & \\
$\quad$ Kurang Baik & 38 & 63,3 \\
$\quad$ Baik & 22 & 36,7 \\
Promosi Kesehatan & & \\
$\quad$ Tidak Pernah & 34 & 53,3 \\
$\quad$ Pernah & 26 & 43,3 \\
Peran Masyarakat & & \\
$\quad$ Kurang Baik & 32 & 53,3 \\
$\quad$ Baik & 28 & 46,7 \\
Peran Orang Tua & & \\
$\quad$ Kurang Baik & 41 & 68,3 \\
$\quad$ Baik & 19 & 31,7 \\
\hline
\end{tabular}

Sumber : Data Primer 2018

Berdasarkan data pada tabel 1 menunjukkan bahwa didapatkan 38 responden $(63,3 \%)$ memiliki perilaku kurang baik karena masih banyak orang tua yang tidak mengenalkan perbedaan jenis kelamin laki-laki dan perempuan dan mengenalkan normanorma pendidikan seks dalam pencegahan pedofilia. Promosi kesehatan didapatkan 34 responden $(53,3 \%)$ tidak pernah mendapat promosi kesehatan tentang pencegahan pedofilia baik melalui penyuluhan dan sumber informasi dalam promosi kesehatan. Peran masyarakat di dapatkan 32 responden $(53,3 \%)$ peran masyarkat didapatkan Kurang baik dalam pencegahan pedofilia. Dari 60 responden di TK Almu'awwanah Tangerang Tahun 2018, di dapatkan 41 responden $(68,3 \%)$ orang tua didapatkan kurang baik sebagai pendidik dan pengawas dalam pencegahan pedofilia. Berdasarkan data tabel 2 diperoleh bahwa responden yang memiliki perilaku kurang baik dan tidak pernah mendapatkan promosi kesehatan ada sebanyak $30(88,2 \%)$ dari total 34 responden, sedangkan responden yang memiliki perilaku baik dan pernah mendapatkan promosi kesehatan ada sebanyak $18(69,2 \%)$ dari total 26 responden. Hasil analisa chi-square di dapat nilai $\mathrm{p}$ value $=0.000$ berarti $p<0,05$ yang artinya ada hubungan antara promosi kesehatan dengan 
Tabel 2. Hubungan Hubungan Promosi Kesehatan, Peran Masyarakat Dan Peran Orang Tua Terhadap Perilaku Pencegahan Pedofilia Pada Anak 2-6 Tahun Di TK Almu'awwanah Tangerang Tahun 2018

\begin{tabular}{|c|c|c|c|c|c|c|c|c|}
\hline \multirow{3}{*}{ Variabel } & \multicolumn{4}{|c|}{ Perilaku } & & & \multirow{3}{*}{$\begin{array}{c}P \\
\text { value }\end{array}$} & \multirow{3}{*}{ OR } \\
\hline & \multicolumn{2}{|c|}{ Kurang baik } & \multicolumn{2}{|c|}{ Baik } & \multicolumn{2}{|c|}{ Total } & & \\
\hline & $\mathbf{N}$ & $\%$ & $\mathbf{N}$ & $\%$ & $\mathbf{N}$ & $\%$ & & \\
\hline \multicolumn{9}{|c|}{$\overline{\text { Promosi Kesehatan }}$} \\
\hline Tidak Pernah & 30 & 88,2 & 4 & 11,8 & 34 & 100 & \multirow{3}{*}{0,000} & \\
\hline Pernah & 8 & 30,8 & 18 & 69,2 & 26 & 100 & & $\begin{array}{c}16,875 \\
(4441-64120)\end{array}$ \\
\hline \multicolumn{8}{|c|}{ Peran Masyarakat } & \\
\hline Kurang Baik & 28 & 87,5 & 4 & 12,5 & 32 & 100 & \multirow{3}{*}{0,000} & \\
\hline Baik & 10 & 35,7 & 18 & 64,3 & 28 & 100 & & $\begin{array}{c}12,600 \\
(3427-46324)\end{array}$ \\
\hline \multicolumn{8}{|l|}{ Peran Orang Tua } & \\
\hline Kurang Baik & 33 & 80,5 & 8 & 19,5 & 41 & 100 & \multirow{2}{*}{0,000} & 11,550 \\
\hline Baik & 5 & 26,3 & 14 & 73,3 & 19 & 100 & & $(3,210-41,555)$ \\
\hline
\end{tabular}

Sumber : Data Primer 2018

perilaku pencegahan pedofilia pada anak 2-6 tahun. Dari hasil analisis di peroleh nilai OR = 16,875 , yang artinya orang tua yang tidak pernah mendapatkan promosi kesehatan memiliki peluang melakukan perilaku tidak baik dalam pencegahan pedofilia sebanyak 16 kali lebih besar dibandingkan orang tua yang pernah mendapatkan promosi kesehatan.

Hasil analisis bivariat pada tabel 2 diperoleh bahwa responden yang memiliki perilaku kurang baik dengan peran masyarakat kurang baik sebanyak $28(87,5 \%)$ dari total 32 responden. Sedangkan responden yang memiliki perilaku baik dengan peran masyarakat baik sebanyak 18 responden $(64,3 \%)$ dari total 28 responden. Dari hasil analisa uji chi-square di dapat nilai $\mathrm{p}$ value $=$ 0.000 berarti $p<0,05$, yang artinya ada hubungan antara peran masyarakat dengan perilaku pencegahan pedofilia di TK Almu'awwanah Tangerang Tahun 2018. Dari hasil analisis didapat nilai $\mathrm{OR}=12,600$ yang artinya peran masyarakat yang memiliki peluang melakukan perilaku kurang baik dalam pencegahan pedofilia 12 kali lebih besar dibandingkan dengan peran masyarakat yang baik.

Hasil analisis bivariat pada tabel $6.7 \mathrm{di}$ peroleh bahwa responden yang memiliki perilaku kurang baik dengan peran orang tua kurang baik sebanyak 33 responden $(80,5 \%)$ dari total 41 responden. Sedangkan responden yang memiliki perilaku baik dengan peran orang tua baik sebanyak 14 responden $(73,3 \%)$ dari total 19 responden. Dari hasil analisa uji chi-square di dapat nilai $p$ value : 0.000 berarti $p<0,05$, yang artinya ada hubungan antara peran orang tua dengan perilaku pencegahan pedofilia di TK Almu'awwanah Tangerang tahun 2018. Dari hasil analisis di dapat nilai $\mathrm{OR}=11,550$ yang artinya peran orang tua kurang baik memiliki peluang melakukan perilaku kurang baik tentang pencegahan pedofilia 11 kali lebih besar dibandingkan dengan orang tua yang berperan baik.

\section{Pembahasan}

\section{Hubungan Promosi Kesehatan terhadap Perilaku Pencegahan pedofilia pada anak 2- 6 tahun di TK Almu'awwanah Tangerang}

Berdasarkan hasil uji statistik di dapatkan nilai $p$ value $=0,000$ berarti $\mathrm{p}$ value < $\alpha(0,05)$ sehingga dapat disimpulkan ada hubungan promosi kesehatan terhadap perilaku pencegahan pedofilia pada anak 2-6 tahun di TK Almu'awwanah tangerang tahun 2018. Dari hasil analisis di peroleh nilai OR 16,875 artinya orang tua yang tidak pernah mendapat promosi kesehatan memiliki peluang 18 kali melakukan perilaku kurang baik dalam pencegahan pedofilia dibandingkan dengan responden yang pernah mendapat promosi kesehatan.

Hasil penelitian ini sejalan dengan penelitian yang dilakukan Lailatul Firdah, tentang Upaya Promosi Kesehatan Tindak Pedofilia di Provinsi Jawa Timur, didapatkan bahwa berdasarkan pendekatan Precede Proceed terkait perencanaan dan pelaksanaan masing-masing kegiatan dalam upaya promosi kesehatan oleh kedua penyedia layanan korban dan pelaku di kedua instansi dapat terlaksana dengan baik, sesuai dengan jadwal waktu dan tempat yang direncanakan, namun masih secara umum tidak spesifik terkait penanganan kasus tindak pedofilia. ${ }^{10}$ 
Hal ini sesuai dengan teori Surbagus, mengatakan promosi kesehatan adalah adalah metode pendidikan yang dinamis bertujuan agar individu, keluarga dan masyarakat tumbuh pengertian, sikap dan perbuatan yang positif dalam membina dan memelihara kesehatannya. Tujuan utama promosi kesehatan adalah agar masyarakat mampu memelihara dan meningkatkan kesehatan, menciptakan suatu keadaan, yakni perilaku dan lingkungan yang kondusif bagi kesehatan. Dalam hal ini adalah perilaku orang tua dalam memberikan pendidikan seks pada anak usia dini. Berdasarkan sasarannya, metode dan teknik promosi kesehatan dibagi menjadi tiga yaitu metode promosi kesehatan individual metode ini digunakan apabila promotor kesehatan dan sasaran berkomunikasi langsung dengan bertatap muka maupun melalui sarana komunikasi (telepon). Metode ini disebut dengan konseling. Metode promosi kesehatan kelompok yaitu teknik dan metode promosi kesehatan ini digunakan untuk sasaran kelompok. Sasaran kelompok dibedakan menjadi dua yaitu sasaran kelompok kecil dan kelompok besar. Disebut kelompok kecil sasaran terdiri dari 6-15 orang sedangkan kelompok besar 15-50 orang. Metode romosi kesehatan massa jika sasaran promosi kesehatan adalah publik maka metode dan teknik yang digunakan adalah promosi kesehatan massa. Merancang metode promosi kesehatan massa paling sulit, sebab sasaran public sangat hiterogen, baik dilihat dari kelompok umur, tingkat pendidikan, tingkat sosial budaya, dan ekonomi. Kita memahami masing-masing kelompok sasaran yang sangat variatif tersebut berpengaruh terhadap cara merespon, cara mempersepsikan dan pemahaman terhadap pesan-pesan kesehatan. ${ }^{13}$

Menurut asumsi penulis bahwa masih banyaknya orang tua yang tidak pernah mendapatkan promosi kesehatan tentang pencegahan pedofilia dikarena tenaga kesehatan yang masih sedikit sehingga sumber daya manusia untuk melakukan promosi kesehatan seperti Home Care, penyuluhan, dan demostrasi juga terbatas. Terutama di daerahdaerah terpencil di Indonesia. Terbatasnya tenaga kesehatan ini berakibat pada banyak masyarakat yang tidak tersentuh oleh promosi kesehatan ini. Promosi kesehatan tentang pencegahan pedofilia dapat dilakukan dengan penyuluhan, baik secara formal yaitu penyuluhan di tempat-tempat pelayanan kesehatan, pelatihan bagi kader kesehatan, dan secara informal dengan melakukan penyuluhan di tempat arisan, pengajian baik oleh petugas kesehatan maupun dari pemerintah setempat. Semakin tinggi promosi kesehatan tentang pencegahan pedofilia maka diharapkan semakin besar orang tua dalam pencegahan pedofilia pada anaknya.

\section{Hubungan Peran masyarakat terhadap perilaku pencegahan pedofilia pada anak 2- 6 Tahun Di TK Almu'awwanah tahun 2018}

Berdasarkan variabel peran masyarakat menunjukkan bahwa dari 60 responden di TK Almu'awwanah Tangerang tahun 2018, diperoleh bahwa responden yang memiliki perilaku kurang baik dengan peran masyarakat kurang baik sebanyak 28 responden $(87,5 \%)$ dari total 32 responden. Sedangkan responden yang memiliki perilaku baik dengan peran masyarakat baik sebanyak 18 responden $(64,3 \%)$ dari total 28 responden. Hasil analisa uji chi-square di dapat nilai $\mathrm{p}$ value $=0.000$ berarti $p<0,05$, yang artinya ada hubungan antara peran masyarakat dengan perilaku pencegahan pedofilia di TK Almu'awwanah Tangerang Tahun 2018. Dari hasil analisis didapat nilai $\mathrm{OR}=12,600$ yang artinya peran masyarakat yang memiliki peluang melakukan perilaku kurang baik dalam pencegahan pedofilia 12 kali lebih besar dibandingkan dengan peran masyarakat yang baik.

Hasil penelitian ini sejalan dengan penelitian yang dilakukan Meliyawati, tentang Peran Keluarga Sekolah dan Masyarakat dalam Upaya Pencegahan kekerasan Seksual Pada Anak di Desa Astanajapura Kecamatan Astanajapura Kabupaten Cirebon, masyarakatpun ikut berperan andil dalam upaya pencegahan kekerasan seksual pada anak diantaranya yaitu: pertama, mengadakan diskusi seputar anak di dalam majelis ta'lim. Kedua, setelah maghrib anakanak Desa Astanajapura di himbau untuk mengaji al- quran dan tidak di perkanankan bermain jauh dari rumah. Beberapa alternatif pencegahan kekerasan seksual di lakukan oleh Lembaga Perlindungan Anak Terpadu Berbasis Masyarakat (PATBM) melalui sosialisasi dan kampanye anti kekerasan pada anak dengan melibatkan sekolah, orangtua, pemerintah desa, dan anak-anak. ${ }^{14}$

Hal ini sesuai dengan teori menurut Notoatmodjo, Peran masyarakat adalah ikut 
sertanya seluruh anggota masyarakatn dalam memecahkan suatu permasalahan masyarakat tersebut. Partisipasi masyarakat di bidang kesehatan berarti keikutsertaan seluruh anggota masyarakat dalam memecahkan setiap permasalahan. Di dalam hal ini masyarakat sendirilah yang aktif memikirkan, merencanakan, melaksanakan, dan mengevaluasikan program-program kesehatan masyarakatnya. Lembaga atas wadah yang ada di masyarakat hanya dapat mendukung, memotivasi, dan membimbingnya. ${ }^{15}$

Menurut asumsi penulis bahwa peran masyarakat masih kurang baik dalm perilaku pencegahan pedofilia dikarenakan peran masyarakat yang kurang dalam berpartisipasi di dalam organisasi atau sebagai anggota masyarakat itu sendiri.

\section{Hubungan Peran Orang Tua terhadap Pencegahan pedofilia pada anak 2-6 tahun di TK Almu'awwanah tahun 2018}

Berdasarkan variabel peran orang tua menunjukkan di peroleh bahwa responden yang memiliki perilaku kurang baik dengan peran orang tua kurang baik sebanyak 33 responden $(80,5 \%)$ dari total 41 responden. Sedangkan responden yang memiliki perilaku baik dengan peran orang tua baik sebanyak 14 responden $(73,3 \%)$ dari total 19 responden. Dari hasil analisa uji chi-square di dapat nilai $p$ value : 0.000 berarti $P<0,05$, yang artinya ada hubungan antara peran orang tua dengan perilaku pencegahan pedofilia di TK Almu'awwanah Tangerang tahun 2018. Dari hasil analisis di dapat nilai $\mathrm{OR}=11,550$ yang artinya peran orang tua kurang baik memiliki peluang melakukan perilaku kurang baik tentang pencegahan pedofilia 11 kali lebih besar dibandingkan dengan orang tua yang berperan baik.

Hasil penelitian ini sejalan dengan penelitian yang dilakukan Gita pola asuh orang tua, perkembangan moral anak, dan hubungan pola asuh orang tua dengan perkembangan moral anak usia 5-6 tahun di TK Aisyiyah Bustanul Atfhal 3 Pontianak Tenggara. Hasil penelitian menunjukkan $\mathrm{r}_{x y}>$ rtabel $(0,589>0,514)$, yang berarti pada penelitian ini $\mathrm{Ha}$ (hipotesis alternatif) diterima dan Ho (hipotesis nol) ditolak. Kesimpulannya terdapat hubungan yang signifikan antara pola asuh orang tua dengan perkembangan moral anak usia 5-6 tahun. Diharapkan orang tua bias mempertahankan pola asuh yang sudah ada dan menentukan pola asuh yang tepat dan sesuai dengan kebutuhan anak agar perkembangan anak dapat berkembang dengan baik terutama perkembangan moral anak. ${ }^{16}$

Perkembangan moral adalah perubahan penalaran, perasaan, dan perilaku tentang standar mengenai benar dan salah. Perkembangan moral adalah perubahanperubahan perilaku yang terjadi dalam kehidupan anak berkenaan dengan tata cara, kebiasaan, adat, atau standar nilai yang berlaku dalam kelompok sosial. Berdasarkan Undang-Undang Republik Indonesia Nomor 20 Tahun 2003 tentang Sistem Pendidikan Nasional pada pasal 7 ayat 1 berbunyi "Orang tua mempunyai kewajiban untuk mengasuh putra- putrinya, yang dipengaruhi oleh budaya yang ada di lingkungan hidupnya, serta diwarnai oleh sikap-sikap tertentu dalam memelihara, membimbing dan mengarahkan putra-putrinya. Sikap tersebut tercermin dalam pola pengasuhan kepada anak-anaknya, karena masing-masing orang tua mempunyai pola asuh tertentu. Selain itu, orang tua berhak berperan serta dalam memilih satuan pendidikan dan memperoleh informasi tentang perkembangan pendidikan anaknya". ${ }^{17}$

Menurut asumsi penulis masih tingginya kurang peran orang tua terhadap pencegahan pedofilia pada anak, di karenakan banyak orang tua menganggap pencegahan pedofilia yang di berikan kepada anak masih kurang baik belum baik dalam melakukan pencegahan pedofilia pada anak.

\section{Kesimpulan}

Berdasarkan hasil penelitian dan pembahasan yang telah diuraikan pada bab sebelumnyan mengenai hubungan promosi kesehatan, peran masyarakat dan peran orang tua terhadap perilaku pencegahan pedofilia pada anak 2-6 tahun di TK Almu'awwanah tahun 2018. Maka dapat disimpulkan distribusi frekuensi Orang tua yang memiliki perilaku kurang baik dalam pencegahan pedofilia sebanyak didapatkan 38 responden $(63,3 \%)$ tidak pernah mendapat promosi kesehatan sebanyak 34 responden (53,3\%), peran masyarkat didapatkan Kurang baik sebanyak 32 responden $(53,3 \%)$, dan peran orang tua didapatkan kurang baik sebanyak 41 responden $(68,3 \%)$. 
Ada hubungan antara promosi kesehatan dengan perilaku pencegahan pedofilia pada anak 2-6 tahun dimana orang tua yang tidak pernah mendapatkan promosi kesehatan memiliki peluang 16 kali berperilaku kurang baik dalam pencegahan pedofilia.

Ada hubungan antara peran masyarakat dengan perilaku pencegahan pedofilia pada anak 2-6 tahun dimana peran masyarakat yang kurang baik memiliki peluang 12 kali kurang baik dalam pencegahan pedofilia.

Ada hubungan antara peran orang tua dengan perilaku pencegahan pedofilia pada anak 2-6 tahun dimana orang tua yang mempunyai kurang baik memiliki peluang 11 kali berprilaku kurang baik dalam pencegahan pedofilia.

\section{Saran}

Hasil penelitian ini diharapkan sekolah memberikan pemahaman pada anak akan kondisi tubuhnya, pemahaman akan lawan jenisnya, pemahaman untuk menghindarkan dari kekerasan seksual ataupun pelecehan seksual dengan cara melalui media gambar atau poster, lagu, permainan serta video. Pencegahan pedofilia ini harus di terapkan dengan memberikan pendidikan seks pada anak usia dini tetapi sesuai dengan tahap pemahaman anak.

Hasil penelitian ini diharapkan orang tua dapat meningkatkan pengetahuan, kesadaran, menerapkan pencegahan pedofilia dengan cara membaca buku, melalui situs-situs Internet, dan bisa langsung berkonsultasi ketenaga kesehatan serta psikolog. Sehingga orang tua mampu melakukan pencegahan pedofilia pada anak-anaknya dengan baik.

\section{Daftar Pustaka}

1. Komisi Nasional Perlindungan Anak. Kompilasi Pantauan Pelanggaran. Jakarta: Komisi Nasional Perlindungan Anak; 2011.

2. KPAI. Bank Data Perlindungan Anak. Jakarta: KPAI; 2016.

3. Fauzi'ah S. Faktor Penyebab Pelecehan Seksual Terhadap Anak. Jurnal An-. Nisa. 9(2): 81-100; 2016.

4. Solihin L. Tindakan Kekerasan pada Anak dalam Keluarga. Jurnal Pendidikan Penabur No.03.Th.III.Desember; 2004.

5. Husni A. Happy Parenting with Novita Tandry. Jakarta : PT. Bhuana Ilmu Populer; 2015.

6. Santy F. Hubungan pengetahuan orang tua tentang kesehatan seksual pada anak usia 7-12 tahun dengan sikap orang tua dalam pencegahan kekeresan seksual.[Jurnal] Program Studi Ilmu Keperawatan Universitas Riau; 2014.

7. Al-Gifari A. Fiqih Remaja Konteporer. Bandung : Media Qalbu; 2005.

8. Supratiknya A. Mengenal Prilaku Abnormal. Jakarta: PT. Gramedia; 2010.

9. Keligman B. Ilmu Kesehatan Anak Volume 3. Jakarta : Buku Kedokteran; 2013.

10. Lailatul F. Upaya Promosi Kesehatan Tindak Pedofilia Di Provinsi Jawa Timur: [Jurnal] Promosi Kesehatan dan Ilmu Perilaku Fakultas Kesehatan Masyarakat Universitas Jember; 2015.

11. Aswar A. Metodologi Penelitian.Tangerang Selatan: Binarupa Aksara ; 2014.

12. Notoatmodjo S. Metode Penelitian Kesehatan. Jakarta: Rineka Cipta; 2012.

13. Surbagus. Promosi Kesehatan Melalui Pendidikan Kesehatan Masyarakat, Yogyakarta: Gosyen Publishing; 2011.

14. Meliyawati. Peran Keluarga Sekolah dan Masyarakat dalam Upaya Pencegahan kekerasan Seksual Pada Anak di Desa Astanajapura Kecamatan Astanajapura Kabupaten Cirebon. [Jurnal] Institut Agama Islam Negeri (IAIN); 2016.

15. Notoatmodjo S. Perilaku Kesehatan Masyarakat Ilmu Dan Seni. Jakarta: rineka cipta ; 2013.

16. Deviana G. Pengaruh Pola Asuh Orang Tua Terhadap Moral Anak Usia 5-6 Tahun. [Jurnal] Program Studi Pendidikan Guru Pendidikan Anak Usia Dini Fkip Untan; 2015.

17. Santrock. Life-Span Development: Perkembangan Masa-Hidup. Edisi 13. Jilid 1. Alih Bahasa: Widyasinta Benedictine. Jakarta: Erlangga; 2011. 